\title{
THE ELDERLY'S SATISFACTION WITH THE SERVICE QUALITY OF A COMMUNITY GERIATRIC HEALTH PROGRAMME IN INDONESIA: A CROSS- SECTIONAL STUDY
}

\author{
Nursalam Nursalam, Mochamad Cholid Hanafi, Elida Ulfiana \\ Faculty of Nursing, Universitas Airlangga \\ E-mail: cholidcoy@gmail.com
}

\begin{abstract}
Introduction: The achievement of the geriatric health programme is still under a number of government targets and the research about the satisfaction of elderly in contributing to this program still limited. This study aims to identify the correlation between the service quality of a geriatric health programme in the community with the satisfaction of older adults. Methods: The research design was cross-sectional and involved 277 elderly people as the respondents. The service quality was measured using a service quality (SERVQUAL) questionnaire with three different sub-variables of input, process and outcome. The elderly people's satisfaction was examined using several parameters including reliability, assurance, tangibles, empathy and responsiveness (RATER). The data obtained from the questionnaires was analysed using the Spearman Rho test with a significance level of $<0.05$ to determine the correlation between the variables. Results: Good service quality provided satisfaction among the elderly. The Spearman Rho test result for input quality was $p=0.000$ with a correlation coefficient of 0.705 , while the test result for process quality was $\mathrm{p}=0.000$ with a correlation coefficient of 0.750 . The outcome quality was $\mathrm{p}=0.000$ with a correlation coefficient of 0.766. The results showed that there is a relationship between the independent and dependent variables. Conclusions: Good service quality regarding the input, process and output of the service can enhance the satisfaction levels of the elderly. This study can be referred to as a parameter and evaluation for the PHC to maintain and improve the service quality standards for the elderly.
\end{abstract}

Key words: community, elderly, geriatric health programme, satisfaction, service quality

\section{INTRODUCTION}

Indonesia has a programme for the elderly in the community named Pos Layanan Terpadu Lansia or an Integrated Health Service Post for the Elderly (IHSPE). This programme aims to improve elderly people's quality of life and well-being. The service quality of IHSPE is significantly important in order to enhance the satisfaction of the elderly; higher service quality will lead to higher satisfaction levels perceived by the elderly.

According to Badan Penelitian dan Pengembangan Kesehatan (BPPK) (2012), the number of public health centres (PHCs) that have implemented the comprehensive geriatric health programme encompassing promotive, preventive, curative and rehabilitative care from the level of family and society to the secondary or advanced level was only $42.3 \%$. The low number of PHCs implementing the programme was caused by several problems including the unavailability of standardised human resources, facilities, documentation and the reporting system of the geriatric health service as well as the multi-programme coordination, which was not been optimal for maintaining the health of elderly people (Permenkes Nomor 2, 2016).

In 2015, the coverage of the geriatric health programme in the Central Java Province was only $52.83 \%$, with the lowest prevalence in Cilacap Regency reaching only $9.21 \%$, which is far from the minimum service standard target of 60\% (Dinas Kesehatan Provinsi Jawa Tengah, 2016). The coverage of the programme in Surabaya City was $68.31 \%$ in 2015 out of a total population of 219,164 elderly people (Dinas Kesehatan Kota Surabaya, 2016). The low results were caused by several factors including facilities, type of activities, human resources and the distance from the elderly individuals' houses to the IHSPE location (Herdining WP 2013).

Customer satisfaction is a factor that strongly determines the service marketing; otherwise, customer dissatisfaction will lead to low service quality standards in the future (Kotler \& Kevin Lane K, 2009). A study conducted in Rembang, Central Java Province, in 2015 showed that $77.6 \%$ of the respondents were dissatisfied with the IHSPE programme, which was provided by the PHC (Rizqiana A, 2015). In Jember, the dissatisfaction prevalence was $34.38 \%$, while in Surabaya it was $46.20 \%$ (Dony S, 2013; Uswatun H, 2012).

An initial study conducted by researchers showed that Pucang Sewu had 5,673 elderly, who were divided into 13 IHSPE programmes. However, the achievement of the geriatric health programme from the $\mathrm{PHC}$ was 
3,030 people or only $52.22 \%$ of the total population of the elderly, which is still under the minimum service standard targeted by Surabaya City Municipality, which reached $70 \%$.

The interviews were performed with elderly people involving questions around the service quality of the three IHSPEs, including the IHSPEs of Bratang, Kertajaya, and Pucang, in which 8 of 10 respondents expressed their dissatisfaction with the activities of the IHSPE. The dissatisfaction levels were caused by the activities, which were held in a narrow place, with limited seats and parking. On the other hand, the health care provider from the PHC only attended once a month, with the rest of the activities being handled by the cadres. Of the total number of elderly people registered in the IHSPE, the attendance rate was only 60-70, which means that $30-40 \%$ of the elderly did not attend the IHSPE's activities.

Satisfaction is a feeling of pleasure or displeasure that comes from a comparison between the impression of a performance or the results of a service and the expectation of it. If the impression is lower than the expectation, then the clients will be dissatisfied, which leads to them becoming reluctant to revisit the service and to seek another service provider. In contrast, if the impression meets their expectation or is higher than it, then the clients will be satisfied or even strongly satisfied, which tends to attract the clients' loyalty (Lupiyopadi, 2009). In the case of the service quality of the IHSPE, if the IHSPE ignores its clients' level of satisfaction, the dissatisfaction will increase, and their attendance rate will decrease. According to Pusat Data dan Informasi Kemenkes RI (2013), 52.12\% of the elderly on average complain about their health condition, comprising of $50.22 \%$ men and $53.74 \%$ women. Based on the data, the PHC as a health care provider on the first level is expected to provide high-quality health services to the elderly, using the IHSPE to maintain independence, productivity and health among the elderly.

According to the data, the researchers are interested in studying the relationship between elderly people's satisfaction levels and the service quality of the IHSPE in the Pucangsewu District, Surabaya.

\section{MATERIALS AND METHODS}

The study used a cross-sectional design with the cluster sampling method. A total of 1144 elderly people from the 13 IHSPEs of the Pucangsewu District, Surabaya, were randomly selected. 10 IHSPEs with a total membership number of 887 elderly, were then recalculated to 277 elderly individuals as the sample. The data was analysed using Rank Spearman, with a significance level of $p<0.05$.

The service quality was calculated from the reduction of the expectation value average to the realisation value average. The level of expectation was measured using a four-point Likert scale, from 1 ("not important") to 4 ("very important"), while the realisation was measured using a Likert scale from 1 ("very bad") to 4 ("very good"). A final score of 1-3 means "excellent", 0 means "fair" and (-1)-(-3) means "poor". The satisfaction level was calculated from the percentage of the total score to the maximum score. A percentage of 80$100 \%$ means "high", $60-79 \%$ means "moderate" and $<60 \%$ means "low". The score was measured using a four-point Likert scale, from 1 ("very dissatisfied") to 4 ("very satisfied").

The ethical clearance of this study has been assessed and verified by the Ethical Committee of the Faculty of Public Health Universitas Airlangga with approval letter No. 263-KEPK. The ethical principles applied in this study include the principles of beneficence, respect for human dignity, right to justice and right to freedom.

\section{RESULTS}

A total of 215 respondents $(77.6 \%)$ rated the input as excellent, and 232 respondents $(83.3 \%)$ also rated the process as excellent (Table 1). A total of 193 people $(69.7 \%)$ perceived a moderate level of satisfaction for the dimension of reliability and 184 people $(66.4 \%)$ also perceived the level of satisfaction with responsiveness as being moderate (Table 2).

Based on Spearman's rho test for the quality of input, the p-value $=0.000(<0.05)$ and $r=0.705$, which means that $\mathrm{H} 1$ is accepted, in which there is a strong correlation between the quality of input and the satisfaction of the elderly. For the quality of process, the p-value = 
The Elderly's Satisfaction with the Service Quality... (Nursalam Nursalam et.al)

Table 1. Cross tabulation between service quality of IHSPE and satisfaction level of elderly

\begin{tabular}{|c|c|c|c|c|c|c|c|}
\hline \multirow{2}{*}{$\begin{array}{c}\text { Sub } \\
\text { Variable }\end{array}$} & \multicolumn{3}{|c|}{ Service Quality } & \multicolumn{3}{|c|}{ Satisfaction Level } & \multirow{2}{*}{$\begin{array}{l}\text { Total } \\
(\%)\end{array}$} \\
\hline & Category & Frequency & Percentage & Category & Frequency & Percentage & \\
\hline \multirow{9}{*}{ Input } & \multirow{3}{*}{ Excellent } & \multirow{3}{*}{215} & \multirow{3}{*}{77.6} & High & 83 & 30.0 & \multirow{9}{*}{100.0} \\
\hline & & & & Moderate & 132 & 47.7 & \\
\hline & & & & Low & 0 & 0 & \\
\hline & \multirow{3}{*}{ Fair } & \multirow{3}{*}{36} & \multirow{3}{*}{13.0} & High & 3 & 1.1 & \\
\hline & & & & Moderate & 33 & 11.9 & \\
\hline & & & & Low & 0 & 0 & \\
\hline & \multirow{3}{*}{ Poor } & \multirow{3}{*}{26} & \multirow{3}{*}{9.4} & High & 0 & 0 & \\
\hline & & & & Moderate & 0 & 0 & \\
\hline & & & & Low & 26 & 9.4 & \\
\hline \multirow{9}{*}{ Process } & \multirow{3}{*}{ Excellent } & \multirow{3}{*}{232} & \multirow{3}{*}{83.8} & High & 85 & 30.7 & \multirow{9}{*}{100.0} \\
\hline & & & & Moderate & 147 & 53.1 & \\
\hline & & & & Low & 0 & 0 & \\
\hline & \multirow{3}{*}{ Fair } & \multirow{3}{*}{19} & \multirow{3}{*}{6.9} & High & 1 & 0.4 & \\
\hline & & & & Moderate & 18 & 6.5 & \\
\hline & & & & Low & 0 & 0 & \\
\hline & \multirow{3}{*}{ Poor } & \multirow{3}{*}{26} & \multirow{3}{*}{9.4} & High & 0 & 0 & \\
\hline & & & & Moderate & 0 & 0 & \\
\hline & & & & Low & 26 & 9.4 & \\
\hline \multirow{9}{*}{ Outcome } & \multirow{3}{*}{ Excellent } & \multirow{3}{*}{136} & \multirow{3}{*}{49.1} & High & 80 & 28.9 & \multirow{9}{*}{100.0} \\
\hline & & & & Moderate & 56 & 20.2 & \\
\hline & & & & Low & 0 & 0 & \\
\hline & & & & High & 6 & 2.2 & \\
\hline & Fair & 115 & 41.5 & Moderate & 109 & 39.4 & \\
\hline & & & & Low & 0 & 0 & \\
\hline & & & & High & 0 & 0 & \\
\hline & Poor & 26 & 9.4 & Moderate & 0 & 0 & \\
\hline & & & & Low & 26 & 9.4 & \\
\hline
\end{tabular}

$0.000(<0.05)$ and $r=0.750$, which means that $\mathrm{H} 1 \mathrm{was}$ accepted, in which there was a strong correlation between the quality of the process and the satisfaction of the elderly. Meanwhile, the quality of the outcome had p-value $=0.000$ $(<0.05)$ and $\mathrm{r}=0.766$, which means that $\mathrm{H} 1$ was accepted, in which there was a strong correlation between the quality of the outcome and the satisfaction of the elderly (table 3 ).

\section{DISCUSSION}

According to the study, there is a strong correlation between the quality of process and the satisfaction of the elderly. In the quality service process, 147 respondents $(53.1 \%)$ perceived that the process quality was excellent, with a fair level of satisfaction. The service quality process of the IHSPE is a process of interaction between the elderly and the PHC's officers, as well as with the cadres by providing services according to their professional knowledge, considering the values believed by each elderly person. The assessment of the quality process was based on the first question in the questionnaire regarding patient safety, in which the officers always disposed of the used needles in the safety box prepared by the officers after blood sugar and cholesterol checking, so that it would not cause any harm to the elderly after the check-up.

Question number 2 and the satisfaction questionnaire question numbers 3 and 4 were about the dimensions of reliability and assurance, while question number 5 was about the information delivery from the cadres and the officers when conducting health education and promotion activities. The elderly are always involved in determining the theme for the promotion by their needs; thus, they will have aims when coming to the programme. The point of question number 3 in the process quality questionnaire and number 2 in the satisfaction 
Jurnal Ners Vol. 12 No. 2 Oktober 2017: 225-232

Table 2. Frequency distribution based on satisfaction dimension of the elderly in the IHSPE

\begin{tabular}{lcccccc}
\hline \multirow{2}{*}{ Quality Dimension } & Low & \% & Moderate & \% & High & \% \\
\cline { 2 - 7 } & 11 & 4.0 & 193 & 69.7 & 73 & 26.4 \\
\hline Reliability & 28 & 10.1 & 151 & 54.5 & 98 & 35.4 \\
\hline Assurance & 32 & 11.6 & 141 & 50.9 & 104 & 37.5 \\
\hline Tangible & 31 & 11.2 & 153 & 55.2 & 93 & 33.6 \\
\hline Empathy & 18 & 6.5 & 184 & 66.4 & 75 & 27.1 \\
\hline Responsiveness & & &
\end{tabular}

Table 3. Data tabulation of correlation between service quality and elderly's satisfaction

\begin{tabular}{lcccl}
\hline \multicolumn{1}{c}{ Quality } & $\mathbf{R}$ & $\begin{array}{c}\text { Correlation } \\
\text { Strength }\end{array}$ & $\mathbf{p}$ & Results \\
\hline Input & 0.705 & Strong & 0.000 & Significant \\
\hline Process & 0.750 & Strong & 0.000 & Significant \\
\hline Outcome & 0.766 & Strong & 0.000 & Significant \\
\hline
\end{tabular}

questionnaire in the assurance dimension relates to the honesty of officers in conveying the check-up results to the elderly people and the satisfaction questionnaire in the responsiveness dimension was an indicator of the excellent service in the service process of the IHSPE. The results of the check-up were always conveyed honestly to the elderly about their health condition and further examination if necessary, either in the PHC or hospital. The officers also explained what kind of services would be could be conducted in the hospital for the elderly so that they would understand the limitations of the service and would not have inflated expectations of the health services in the IHSPE. The quality of input question number 5 was about the manners and appearance of the cadres of the IHSPE programmes; all of the health cadres always show good manners and communicate well with the elderly in the IHSPE programme.

The results of this study correspond with those of the study conducted by Desi Suci (2014) in Jakarta, which showed that the majority of the respondents stated that the cadres were well-behaved in the IHSPE programmes, paid attention to the elderly, were friendly, and invited the elderly to communicate with them. These results show that the elderly were satisfied with the performance of the IHSPE cadres.

Parasuraman in Nursalam (2015) described the assurance dimension in the concept of the service quality RATER, whereby a service provider organisation guarantees that the service quality will provide satisfaction and high work commitment in accordance with the form of the work integration, work ethic, and work culture according to the vision and mission of the organisation in order to convince people about their service and performance.

The quality of process questionnaire number 3 and satisfaction questionnaire of assurance dimension number 3 and reliability dimension number 5 contained the accuracey and skill of the officers in providing IHSPE services, which means that the officers delivered satisfaction to the elderly by showing their skills in medical examination and treatment by providing the appropriate prescription and drugs to the elderly in accordance with the results of the examination so the elderly perceived the officers as having given a good performance. Question number 7 in the quality questionnaire and satisfaction questionnaire in assurance dimension number 4 was about the disadvantages arising from the IHSPE towards the elderly. During the IHSPE activities, the elderly have never felt disadvantaged, either morally or materially. Officers were always well-behaved when interacting with the elderly, such as using polite word choices and making no distinction regarding grade, class, religion, or ethnicity so that the elderly people felt the officers respected them according to the question number 5 and 6 in the service quality process questionnaire.

The results correspond with those of Donnabedian in Nursalam (2015). The aims of ISO 9001: 2000 ensures the suitability of the service process about the requirements that are specified by the customer and agency service 
providers to maintain the principles of ethics; namely beneficence, non-maleficence, respect and justice in providing the services.

In the quality of the process, 26 respondents $(9.4 \%)$ answered that the process was poor with low satisfaction. The low rating was a result of the services received being lower than the expectation. The elderly were not satisfied regarding the empathy dimension and their complaints about health problems to the cadre and their solution, as reported in the questionnaire of the quality of process number 8 and 9, as well as the questionnaire of empathy satisfaction numbers $1,3,4$, and 5 . These problems happened because of the limited number of officers who have to serve all of the elderly people in the location. Some of the elderly people did not have the opportunity to consult about their health problems. These results correspond with those in the study conducted by Anggri (2011), in which the respondents stated that they were less satisfied with the level of empathy performance and the public service because the cadres often did not pay attention to the elderly person's needs and did administrative work instead. Another study, conducted by Wulansari (2015), stated that the good service and patience of the cadres in dealing with the elderly were two of the factors leading to high satisfaction levels among the elderly in the IHSPE programmes, as they perceived that the benefits of the IHSPE programme that can help to maintain their health condition.

The gap in SERVQUAL theory, according to Nursalam (2015), is a gap between the quality specifications and service delivery, whereby the service standard and delivery are in good order, but the front-line staff have not received specific training on the delivery of the services, which has caused the gap. It prevented the service from meeting the standards set by the service provider.

Some organisations have to adapt to the satisfaction preference of their clients as well as to the best effort that they can provide (Nursalam,2015). In providing the services, the IHSPE must correspond with the job commitment by performing attractive, convincing and trustworthy behaviour as well as the actualisation and reflection of the job performance. It can be achieved including competence in the form of the skills and knowledge possessed by the employees to perform the services; courtesy, including hospitality, the attention and attitude of the employee and then credibility encompassing matters related to the trust towards the company, such as reputation, achievements and any other matters.

Based on demographic data, nearly half of the elderly people's education level was primary school, amounting to 133 respondents $(48.0 \%)$. The education level of the elderly could affect quality perception in the information transmitted by the officers which could have an impact on the level of satisfaction towards the information received by the elderly. The results were in line with the study conducted by Kristina B W (2015), who found that education level could affect the level of the understanding of the respondents about the information received by them. With higher education, the elderly could obtain more information, both from other people and from the media. If they obtained more information, they would also obtain more knowledge. A high level of education also makes it easier for them to access information, so it would improve their competence in performing tasks and have an impact on quality improvement in providing an assessment of the information.

This study has showed that there is a strong correlation between the quality of the outcomes and the satisfaction of the elderly. 109 respondents $(39.4 \%)$ perceived that the quality of outcomes was excellent, with a moderate level of satisfaction. The outcome is a result of the services provided by the service provider institutions, in the form of changes perceived by the consumers including their satisfaction. In the quality of outcomes questionnaire, question numbers 2 and three about Clean and Healthy Lifestyle Behaviour gave an indicator of the success of the quality outcome, in which the elderly had adopted a clean and healthy lifestyle and conducted physical activities for maintaining their health.

There were 26 respondents $(9.4 \%)$ who perceived a poor quality level of outcome with a low level of satisfaction. These low results were caused by the outcome that the IHSPE could not 
provide satisfaction to the elderly, as the service received by them was lower than their expectation about the quality of outcomes. The quality of outcome questionnaire question number 1 about blood pressure and blood glucose condition was one factor to do with the low rating of service quality of the IHSPE outcome. The elderly people who come upon the IHSPE treatment activities will be reliant on medication to maintain their blood glucose level and blood pressure. Some health promotion activities that are held in the IHSPE educate the elderly people about how to control their blood pressure and blood glucose levels in other ways besides medication, such as a healthy diet, physical activities, stress management and routine control. The expectation of the elderly about their treatment and medication in the IHSPE can lead to them providing a poor assessment of the quality level because they may not understand that there is another alternative to keep their blood glucose and blood pressure under control due to their absence in several IHSPE sections. These results support the research conducted by Kristina B W (2015), who found that respondents with less experience in IHSPE activities have less appreciation of the benefits of IHSPE activities, and end up giving a low rating because of their negative attitude.

Based on the demographic data, most of the elderly still had routine activities or work numbering 186 respondents $(67.1 \%)$. One factor preventing the respondents from attending the IHSPE routinely was their routine activity; for example, working as traders, either in the home or at a market. The elderly assumed that their activities were more important than coming to the IHSPE because they had no financial benefits from the IHSPE so could not establish a positive attitude. The results of this study support Hutabarat (2012)'s statement that the respondents who gained a benefit from the IHSPE showed a positive attitude because of their good experience towards the benefits they perceived, so the elderly stated that the IHSPE was very important for both healthy and sick elderly people. Among the respondents who did not benefit from the IHSPE, most had a negative attitude towards IHSPE. They assumed that IHSPE activities were not useful because the doctors never performed a medical check-up.
This result corresponds with those of a study conducted by Zarniyeti (2011), which stated that the respondents who benefited from IHSPE had a more positive attitude towards the IHSPE activities compared to the respondents who did not benefit from IHSPE, causing a negative attitude towards the existing services of the IHSPE.

Personal experience could affect someone's attitude; something that has previously happened or is currently happening in our lives will influence our appreciation of the stimulus. Little or no experience of an object tends to form a negative attitude towards the object (Anwar, 2008). Elderly people who rarely come to the IHSPE activities and only come during treatment activities are likely to show a negative attitude towards the IHSPE activities because they cannot perceive the benefit of the IHSPE activities. Some of the elderly people just came because of necessity, for a health check-up and for the treatment of their disease. This is in line with Parasuraman's statement in Nursalam (2015), that the rating related to the quality and satisfaction depends on the personal needs in which the customers' expectations vary, depending on the individual's characteristics and the circumstances that affect their personal needs. Elderly people who only expect treatment in the IHSPE are likely to provide a low rating for the quality of the other IHSPE activities besides the medical check-up and treatment, and do not perceive any benefit (outcomes) resulting from the IHSPE overall.

\section{CONCLUSIONS}

The service quality among the three subvariables encompassing input, process, and outcome could determine the elderly people's level of satisfaction towards the IHSPE service. The good quality of input increases the elderly people's satisfaction through the development of human resources, cost and facilities as well as the implementation of modern technology in the IHSPE service. A good quality of process can increase the elderly person's satisfaction through upholding service ethics encompassing a good attitude, non-maleficence, respect for the elderly, and the right to justice in the IHSPE service. A good quality outcome can increase 
the elderly people's satisfaction through their health status, behaviour and the attitude of the elderly in the IHSPE.

This study can be used by the PHC as a reference to enhance the quality of input, process, and the outcomes of the IHSPE service. This study also provides an insight for the elderly on how to give an appraisal of the IHSPE service, allowing the elderly to contribute to maintaining and enhancing the quality of the IHSPE service. Further study is needed to conduct an internal study of the service quality of the PHC and IHSPE programme so that it can be compared to the external study of the perceptions of the elderly, as currently conducted by the authors.

\section{REFERENCES}

Aaker, D, A., 1996. Measuring Brand Equity Across Products and Market. California Manajemen Review, 38, pp.102.

Angga, D, S., 2014. Pengukuran Tingkat Kepuasan Pelanggan Terhadap Kualitas Pelayanan Dengan Metode Servqual "Studi Kasus Pada Pusat Oleh Oleh Harum Manis." Universitas Brawijaya.

Anggri, V., 2011. Analisis Kepuasan Pelanggan Terhadap Kualitas Pelayanan Jasa Pos Express Di PT. Pos Indonesia Cabang Surakarta. Universitas Sebelas Maret Surakarta.

Azwar 2008. Sikap Manusia, Teori dan Pengukurannya 2nd ed., Yogyakarta: Pustaka Pelajar.

Badan Penelitian dan Pengembangan Kesehatan., 2012. Riset Fasilitas Kesehatan, Jakarta: Kementerian Kesehatan Republik Indonesia.

Christine, H., 2012. Studi Kulaitatif PemanfaatanPosyandu Lansia di Wilayah Puskesmas Sarudik Kabupaten Tapanuli Tengah. FakultasKesehatan Masyarakat Universitas Indonesia.

Desi, S, A., 2014. Hubungan Antara Kinerja Kader Posyandu Terhadap Kepuasan Lansia di Kelurahan Rempoa Timur Jakarta. Universitas Islam Negeri Syarif Hidayatullah.

Dewi, E, H., 2012. Pemanfaatan Pos Pembinaan Terpadu Oleh Lanjut Usia Di
Kecamatan Ciomas Kabupaten Bogor Tahun 2012 Dan Faktor Yang Berhubungan, Jakarta. Fakultas Kesehatan Masyarakat Program Sarjana Kesehatan Masyarakat Universitas Indonesia.

Diana, S., 2010. Manajemen Pemasaran Usaha Kesehatan 4th ed., Yogyakarta: Nuha Medika.

Dinas Kesehatan Kota Surabaya., 2016. Profil Dinas Kesehatan Kota Surabaya Tahun 2015, Surabaya: Dinas Kesehatan Kota Surabaya.

Dinas Kesehatan Provinsi Jawa Tengah., 2016. Profil Kesehatan Kabupaten dan Kota di Jawa Tengah Tahun 2015, Semarang: Dinas Kesehatan Provinsi Jawa Tengah.

Dony, S., 2013. Hubungan Pelayanan Posyandu Lansia dengan Tingkat Kepuasan Lansia di Wilayah Kerja Puskesmas Sukorambi Kabupaten Jember. STIKES Bhakti Negara Jember.

Fitrah, W., 2010. Memahami Kesehatan Pada Lansia 3rd ed., Jakarta: CV. Trans Info Media.

Green, L W., 1980. Health Program Planning An Educational and Ecological Approach, Marshall W. Kreuter: Rollins School of Public Health of Emory University.

Herdining, W, P., 2013. Faktor-Faktor Yang Berhubungan Dengan Frekuensi Kehadiran Lanjut Usia Di Posyandu Lansia. Jurnal Ilmiah Kebidanan, 2(4 Juni 2013), pp.1

Hesti, W., 2010. Analisis Faktor-Faktor Yang Mempengaruhi Pemanfaatan Posyandu Lansia di gantungan - Makam Haji Surakarta. Universitas Muhammadiyah Surakarta.

Kementerian Kesehatan Republik Indonesia., 2010., Pedoman Pengelolaan Kesehatan di Kelompok Lanjut Usia, Jakarta: Direktorat Bina Upaya Kesehatan.

Kementerian Kesehatan Republik Indonesia., 2009. Undang - Undang Kesehatan Nomor 36, Jakarta: Kementerian Kesehatan Republik Indonesia.

Kementerian Kesehatan Republik Indonesia., 2013. Pedoman Pembinaan Kesehatan Usia Lanjut., Jakarta: Direktorat Bina 
Upaya Kesehatan.

Kepmenkes Nomor 52., 2015. Rencana Strategis Kementerian Kesehatan Tahun 2015 2019, Jakarta: Kementerian Kesehatan Republik Indonesia.

Kotler, K, L., 2009. Manajemen Pemasaran 13th ed., Jakarta: Erlangga.

Kristina, B, W, 2015., Pengaruh Pendidikan Kesehatan dengan Media Audio Visual Terhadap Perilaku Ibu Dalam Penanganan Infeksi Saluran Pernafasan Akut Pada Balita di Kelurahan Lebijaga Kabupeten Ngada. Universitas Airlangga Surabaya.

Lupiyopadi, R., 2009. Manajemen Pemasaran Jasa 2nd ed., Jakarta: Salemba Empat.

Nursalam, 2015. Manajemen Keperawatan, Aplikasi dalam Praktek keperawatan Profesional, Jakarta: Salemba Medika.

Nursalam, 2013. Metodologi Penelitian Ilmu Keperawatan, Pendekatan Praktis, Jakarta: Salemba Medika.

Parasuraman \& Zeithaml, A., 1985. A Conceptual Model of Service Quality and Its Impact for Future Research. Journal of Marketing, III, pp.41-50.

Parasuraman \& Zeithaml 1988. SERVQUAL : A Multiple - Item Scale for Measuring Consumer Perception of Service Quality. Research Gate, II, pp.13-16.

Permenkes Nomor 25., 2016. Rencana Aksi Nasional Kesehatan Lanjut Usia Tahun 2016 - 2019, Jakarta: Kementerian Kesehatan Republik Indonesia.

Permenkes Nomor 75., 2014. Pusat Kesehatan Masyarakat, Jakarta: Kementerian Kesehatan Republik Indonesia.

Pusat Data dan Informasi Kemenkes RI., 2013. Buletin Lansia: Gambaran Kesehatan
Lansia di Indonesia, Jakarta: Kementerian Kesehatan Republik Indonesia.

Rizqiana, A., 2015. Kualitas Pelayanan Kesehatan di Puskesmas Sedan Kabupaten Rembang. Program Studi Ilmu Keperawatan, Fakultas Kedokteran UIN Syarif Hidayatullah Jakarta.

Sulistyorini., 2010. Posyandu dan Desa Siaga 1st ed., Yogyakarta: Nuha Medika.

Titi, W., 2015. Studi Deskriptif Implementasi Program Posyandu Lanjut Usia di RW IV Kelurahan Tanah Kali Kedinding Kecamatan Kenjeran Surabaya. Kebijakan dan Manajemen Publik, 3(Januari-April 2015).

Uswatun, H., 2012. Faktor - Faktor Yang Mempengaruhi Kepuasan Lansia di Posyandu Lansia Kelurahan Wonokusumo Kecamatan Semampir Kota Surabaya, Surabaya. Fakultas Ilmu Kesehatan Universitas Muhammadiyah Surabaya.

Yunus, M, B., 2013. Pengaruh Kualitas Pelayanan Terhadap Kepuasan Pelanggan pada PT. PLN (Persero) Rayon Makassar Barat. Universitas Hasanudin Makasar.

Zarniyeti., 2011. Analisis Faktor-faktor yang Berhubungan dengan Pemanfaatan Posyandu Lansia oleh Lanjut Usia ( > 60 tahun) di Wilayah Kota Pariaman Sumatera Barat Tahun 2011. Fakultas Kesehatan Masyarakat Universitas Indonesia.

Zulian, Y., 2013. Manajemen Kualitas Produk dan Jasa, Yogyakarta: Fakultas Ekonomi Universitas Islam Indonesia. 